\title{
Uji Aktivitas Antibakteri Ekstrak Metanol dan Fraksi Daun Kenikir (Cosmos caudatus Kunth) terhadap Salmonella typhi
}

\section{(Antibacterial activity test of methanol extract and fraction of Kenikir Leaves (Cosmos caudatus Kunth) against Salmonella typhi)}

\author{
Bawon Triatmoko, Achmad Syarifudin Noor, Nuri \\ Fakultas Farmasi Universitas JemberJL. Kalimantan 37, Jember 68121 \\ e-mail korespondensi: bawon.farmasi@unej.ac.id
}

\begin{abstract}
The leaves of kenikir are known to have many benefits, one of which can be used as medicine. Kenikir leaves are reported to have antibacterial activity against the bacteria Salmonella typhi (S.typhi). S. typhi is a bacterium that causes typhoid fever. Typhoid fever is still an endemic disease in Asian countries, especially Indonesia. Typhoid fever became the third largest disease in Indonesia in 2010. The study related to the antibacterial activity of kenikir leaf fraction to $S$. typhi has never been reported. Therefore, it is necessary to conduct research related to the antibacterial activity of extracts and leaf fractions of kenikir to compare their potential against S. typhi. The study was conducted using the disk diffusion method using 5 series of concentrations namely 5\%, 10\%, 15\%, 20\%, and 30\%. Tests were carried out on methanol extract, hexane, ethyl acetate, and methanol-water fraction. The results showed that highest inhibition zone diameter is $7,75 \mathrm{~mm}$ which is reached by methanol extract. The order of the highest inhibiting zone diameter are extract, hexane, ethyl acetate, and methanol- water fraction.
\end{abstract}

Keywords: Kenikir leaves, antibacterial activity, S. typhi

\begin{abstract}
Abstrak
Daun kenikir diketahui memiliki banyak manfaat salah satunya dapat digunakan sebagai obat. Daun kenikir dilaporkan memiliki aktivitas antibakteri terhadap bakteri Salmonella typhi (S.typhi). S. typhi merupakan bakteri penyebab terjadinya demam tifoid. Demam tifoid masihmenjadi penyakit endemik di negara-negara Asia khususnya Indonesia. Demam tifoid menjadi penyakit dengan urutan ketiga pasien rawat inap terbesar di Indonesia pada tahun 2010. Penelitian terkait aktivitas antibakteri fraksi daun kenikir terhadap $S$. typhi belum pernah dilaporkan. Oleh sebab itu perlu dilakukan penelitian terkait aktivitas antibakteri ekstrak dan fraksi daun kenikir untukmembandingkan potensinya terhadap $S$. typhi. Penelitian dilakukan menggunakan metode difusi cakram dengan menggunakan 5 konsentrasi yakni $5 \%, 10 \%, 15 \%, 20 \%$,dan 30\%. Pengujian dilakukan pada ekstrak methanol, fraksi heksana, fraksi etil asetat, dan fraksi metanol-air. Hasil penelitian menunjukkan bahwa ekstrak metanol memiliki diameter zona hambat paling besar senilai $7,75 \mathrm{~mm}$ dibandingkan dengan fraksi-fraksi uji. Adapun urutan diameter zona hambatterbesar yakni ekstrak, fraksi heksana, etil asetat, dan metanol air.
\end{abstract}

Kata kunci: Daun kenikir, antibakteri, S. typhi

\section{Pendahuluan}

Indonesia merupakan negara dengan keanekaragaman hayati terbesar nomor dua di bawah Brazil dengan jumlah jenis tanaman lebih dari 30.000 jenis tanaman [1] . Nenek moyang bangsa Indonesia sejak dahulu banyak memanfaatkan tanaman-tanaman berkhasiat sebagai obat [2]. Sebanyak 431 tanaman terbukti dapat digunakan sebagai tanaman obat pada beberapa penyakit diantaranya yakni kenikir [3]. Kenikir (Cosmos caudatus Kunth) merupakan tanaman asli dataran Amerika dan tersebar di daerah-daerah dengan iklim tropis [4]. Kenikir tumbuh dengan baik pada daerah dengan intensitas sinar matahari penuh dan tumbuh sampai ketinggian $700 \mathrm{mdpl}$ [5]. 
Kenikir banyak dimanfaatkan oleh masyarakat Indonesia sebagai tanaman obat. Secara empiris, kenikir dimanfaatkan untuk melancarkan buang air besar, mengobati batuk, sakit gigi, hingga infeksi cacing [6]. Pada masyarakat melayu, batang dan daun kenikir juga digunakan untuk merawat dan menyembuhkan penyakit infeksi dan sebagai agen anti penuaan [7]. Dari seluruh bagian tanaman ini, daunnya telah diketahui memiliki beberapa kandungan diantaranya flavonoid, saponin, tanin, dan alkaloid $[8,9]$.

Penelitian lebih lanjut menunjukkan bahwa kenikir memiliki aktivitas antibakteri. Ekstrak daun kenikir mampu memberikan aktivitas antibakteri pada bakteri gram positif seperti Staphylococcus aureus, methicillinresistant Staphylococcus aureus, dan Bacillus cereus [10- 12]. Ekstrak daun kenikir juga memberikan aktivitas terhadap bakteri gram negatif seperti Shigella sp. dan Salmonella typhi (S. typhi) $[13,14]$. Pada penelitian yang sudah ada, belum dilakukan penelitian terhadap fraksi ekstrak metanol daun kenikir terhadap S. typhi.

$S$. typhi dapat menyebabkan penyakit typoid atau yang dikenal dengan demam tifoid. Demam tifoid merupakan penyakit yang perlu diperhatikan, khususnya di negara berkembang. Penyakit ini menjadi penyakit endemik di negara asia seperti Cina, India, Pakistan, Vietnam dan Indonesia [15]. Menurut Riset Kesehatan Dasar Nasional pada tahun 2007, angka prevalensi demam tifoid di Indonesia mencapai 1,5\% atau setidaknya terdapat 1.500 kasus tiap 100.000 penduduk [16]. Berdasarkan data Kemenkes pada tahun 2010, dilaporkan bahwa demam tifoid menjadi penyakit dengan urutan ketiga pasien rawat inap terbesar di Indonesia pada tahun 2010 dengan angka kejadian sebesar 41.081 kasus dan kematian sebesar 274 orang[17]

Berdasarkan hal tersebut akan dilakukan penelitian untuk mengetahui aktivitas ekstrak metanol dan beberapa fraksi dari daun kenikir (Cosmos caudatus) terhadap bakteri $S$. typhi. Adapun fraksi yang digunakan pada penelitian ini yaitu fraksi heksana, etil asetat, dan air. Metode yang dipilih dalam penelitian ini yakni metode difusi cakram untuk mengetahui zona hambat ekstrak dan fraksi terhadap S. typhi. Diharapkan penelitian ini dapat memberikan informasi tentang kelompok senyawa aktif yang lebih

memiliki aktivitas antibakteri dengan membandingkan ekstrak dan fraksi yang terdapat pada daun kenikir.

\section{Metode Penelitian}

Alat yang digunakan pada penelitian ini yakni jangka sorong (TRICLE BRAND), oven (MEM-MERT), vortex (HEIDOLPH), hot plate (UC-152), Laminar Air Flow (AIRTECH), inkubator (18-ONE SIC 50L), dan autoklaf (ALP). Adapun bahan yang digunakan antara lain serbuk daun kenikir (Cosmos caudatus kunt) dari Materia Medika, Batu. Bahan kimia yang digunakan yakni metanol terdestilasi, heksana, etil asetat. Bahan yang digunakan untuk pengujian aktivitas antibakteri antara lain kloramfenikol, dimetil-sulfoksida (DMSO), dan akuades steril. Bakteri uji yang digunakan ialah Salmonella typhi. Adapun media bakteri yang digunakan adalah Muller Hinton Agar (MHA).

Serbuk daun kenikir sejumlah 100 gram dilarutkan dalam metanol dengan rasio 1:5 sehingga dibutuhkan metanol sejumlah $500 \mathrm{ml}$. Ekstraksi dilakukan secara maserasi pada suhu ruang selama 24 jam dengan pengadukan yang dibantu magnetic stirrer dengan kecepatan 200 rpm. Hasil ekstraksi kemudian dikeringkan dan selanjutnya dilakukan fraksinasi dengan metode partisi cair-cair. Proses fraksinasi dilakukan secara bertingkat dengan urutan fraksi heksana untuk menarik senyawa non polar, etil asetat menarik senyawa semipolar, dan terakhir fraksi metanol air untuk menarik senyawa polar.

Skrining fitokimia dilakukan dengan metode uji tabung. Skrining ini digunakan untuk mengetahui golongan senyawa yang terdapat dalam ekstrak dan fraksi daun kenikir. Metode ini ditujukan untuk mengidentifikasi adanya golon-gan senyawa seperti alkaloid, flavonoid, saponin, dan tanin.

Pembuatan media Muller Hinton Agar (MHA) digunakan untuk peremajaan bakteri uji. Sebanyak 9,5 gram media dilarutkan dengan akuades demineralisata dalam erlenmeyer 250 $\mathrm{ml}$ hingga mendidih menggunakan hot plate. Dilakukan sterilisasi pada suspensi dengan autoklaf pada suhu $121^{\circ} \mathrm{C}$ dengan tekanan udara 1 atm dalam 15 menit. Kemudian media dipanaskan hingga mencair dan diletakkan ke dalam cawan petri steril. Cawan petri tersebut dimasukkan ke dalam Laminar Air Flow (LAF) hingga memadat. 
Peremajaan biakan murni pada media MHA dilakukan di dalam Laminar Air Flow (LAF) secara aseptis. Jarum ose yang sudah mengandung $S$. typhi digoreskan ke media padat. Cawan petri dibungkus menggunakan platic wrap, selanjutnya diinkubasi pada inkubator pada suhu $37^{\circ} \mathrm{C}$ selama 24 jam.

Metode yang dipilih untuk menentukan zona hambat aktivitas antibakteri dari daun keni-

kir adalah difusi cakram. Uji antibakteri dibedakan menjadi 2 kelompok yakni kelompok uji dan kelompok perlakuan. Kelompok uji yang digunakan pada penelitian ini terdiri dari kontrol negatif yakni

DMSO $10 \%$ dan kloramfenikol $30 \mu \mathrm{g} / \mathrm{ml}$ sebagai kontrol positif. Adapun Kelompok perlakuan terdiri dari konsentrasi ekstrak dan fraksi sebesar $5,10,15,20$, dan $30 \%$.

Data uji aktivitas ekstrak dan fraksi yang telah diperoleh kemudian diolah secara statistika. Uji statistika dilakukan secara non parametrik dengan uji Kruskal Wallis. Selanjutnya dilakukan uji Mann Whitney untuk mengetahui data yang memiliki perbedaan signifikan.

\section{Hasil Penelitian}

Skrining fitokimia dilakukan dengan metode uji tabung. Hasil uji skrining fitokimia menunjukkan ekstrak daun kenikir, fraksi heksana, dan etil asetat mengandung golongan sen-yawa flavonoid, saponin, dan polifenol. Sedangkan pada fraksi metanol-air hanya mengandung senyawa flavonoid dan polifenol saja.

Hasil uji aktivitas antibakteri menunjukkan bahwa terdapat aktivitas pada semua konsentrasi ekstrak dan fraksi heksana, serta beberapa konsentrasi pada fraksi etil asetat. Sedangkan pada fraksi metanol-air tidak memberikan aktivitas antibakteri.

Hasil uji aktivitas antibakteri ekstrak dengan tiap fraksi menunjukkan hasil yang bervariasi. Oleh karena itu dipilih satu seri konsentrasi terendah pada ekstrak untuk dibandingkan dengan konsentrasi terendah tiap fraksi. Konsen-trasi terendah dipilih untuk melihat pada konsen-trasi berapa sampel uji sudah dapat memberikan aktivitas antibakteri pada S. typhi. Hal tersebut dapat dilihat pada Gambar 5.

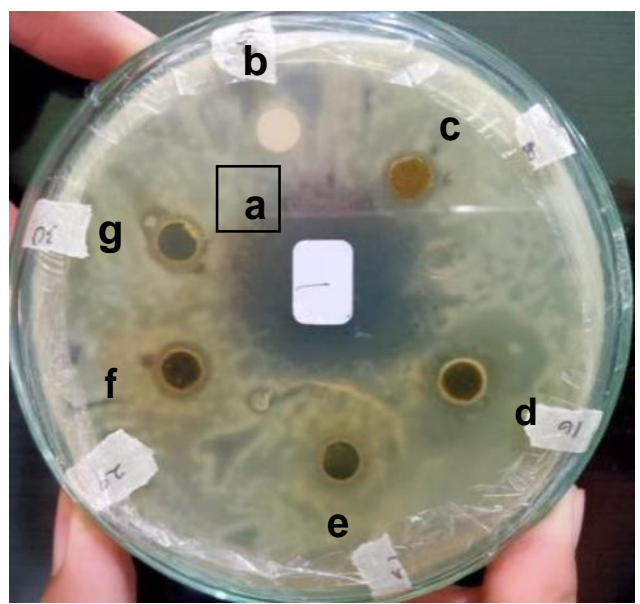

Gambar 1. Hasil uji antibakteri pada fraksi heksana konsentrasi c) $5 \%$; d) $10 \%$; e) $15 \%$; f) $20 \%$; g) $30 \%$; a) kontrol positif; b) kontrol negatif

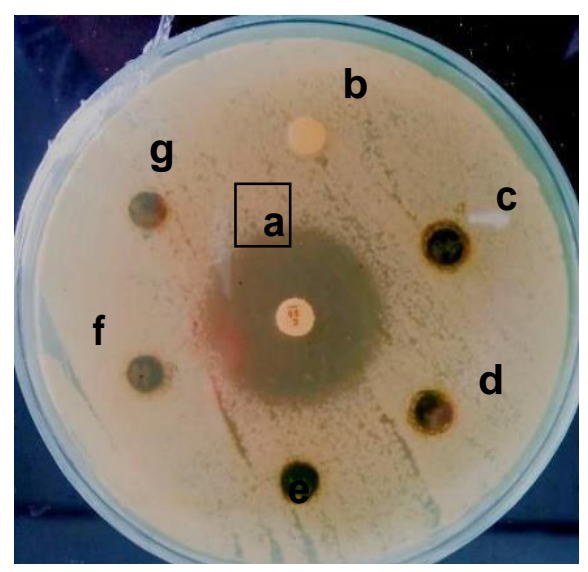

Gambar 2. Hasil uji antibakteri pada fraksi heksana konsentrasi c) $5 \%$; d) $10 \%$; e) $15 \%$; f) $20 \%$; g) $30 \%$; a) kontrol positif; b) kontrol negatif 
sebagai kontrol negatif. DMSO merupakan pelarut yang mampu melarutkan senyawa yang bersifat non polar maupun polar. Hal ini menjadi alasan peneliti menggunakan DMSO sebagai pelarut pada ekstrak maupun fraksi uji. Hasil penelitian menunjukkan bahwa DMSO 10\% tidak memiliki aktivitas antibakteri terhadap S.typhi dengan tidak adanya zona hambat pada kontrol negatif.

Kontrol positif yang digunakan adalah kloramfenikol $30 \mu \mathrm{g} / \mathrm{mL}$. Kontrol positif kloramfenikol memberikan zona hambat $\pm 31-32$ $\mathrm{mm}$. Hal ini menunjukkan kloramfenikol masih sensitif terhadap S.typhi. Penggunaan kontrol positif ini ditujukan untuk memastikan metode uji yang dilakukan apakah sudah valid.

Hasil uji aktivitas antibakteri pada ekstrak, fraksi heksana, dan fraksi metanol air dengan berbagai konsentrasi dinotasikan dengan huruf a yang menunjukkan pada ketiga sampel uji dengan konsentrasi yang berbeda tidak memiliki perbedaan yang bermakna. Sedangkan huruf $b$ menunjukkan perbedaan yang bermakna dengan data yang memiliki notasi huruf a. Hasil tersebut ditunjukkan oleh fraksi etil asetat. Pada fraksi ini didapatkan perbedaan bermakna pada konsentrasi 5\%, 10\%, 15\% yang dinotasikan dengan notasi huruf a dengan 20\% dan 30\% yang dinotasikan dengan huruf $b$. Adanya perbedaan yang tidak bermakna tersebut kemungkinan disebabkan karena pada tiap konsentrasi yang digunakan untuk uji aktivitas antibakteri memiliki kemampuan untuk menghambat S.typhi yang hampir sama. Begitu juga sebaliknya, jika pada uji statistik menunjukkan adanya perbedaan bermakna maka konsentrasi tersebut memiliki aktivitas yang berbeda.

Hasil uji aktivitas antibakteri ekstrak dengan tiap fraksi menunjukkan hasil yang bervariasi maka dipilih satu seri konsentrasi terendah pada ekstrak untuk dibandingkan dengan konsentrasi terendah tiap fraksi. Konsentrasi terendah dipilih untuk melihat pada konsentrasi berapa sampel uji sudah dapat memberikan aktivitas antibakteri pada S. typhi. Berdasarkan Gambar 5, zona hambat yang dihasilkan oleh ekstrak metanol daun kenikir pada konsentrasi 5\% menunjukkan aktivitas antibakteri tertinggi terhadap $S$. typhi jika dibandingkan dengan seluruh fraksi uji yang secara berurutan diikuti oleh fraksi heksana, etil asetat, dan metanol air.

Aktivitas antibakteri pada sampel dapat dipengaruhi oleh golongan dari metabolit sekunderyangmampumenghambat pertumbuhan bakteri. Aktivitas tersebut dapat berasal dari mekanisme kerja suatu senyawa secara individu maupun gabungan dari mekanisme senyawa-senyawa yang terkandung di dalamnya [18]. Terdapat kemungkinan besarnya zona hambat yang dihasilkan ekstrak daun kenikir terjadiakibat adanya sifat sinergitas antar mekanisme senyawa di dalam ekstrak. Hal ini yang menyebabkan ekstrak metanol daun kenikir memiliki diameter zona hambat tertinggi dibandingkan fraksi uji. Adapun dugaan lain yaitu terjadi pemisahan yang kurang sempurna pada proses fraksinasi sehingga penarikan senyawa oleh pelarut yang sesuai tidak sempurna, selain itu terdapat kemungkinan terjadi dekomposisi selama proses fraksinasi sehingga senyawa-senyawa yang terkandung dalam fraksi menjadi rusak atau aktivitas antibakterinya menurun [19].

Hasil skrining fitokimia menunjukkan bahwa ekstrak metanol daun kenikir menunjukkan adanya senyawa golongan flavonoid, saponin, dan tanin. Senyawa golongan flavonoid yang banyak terkandung pada kenikir yaitu kuersetin dan katekin [20]. Kuersetin mampu menghambat bakteri baik gram positif maupun negatif dengan menginaktivasi protein seluler [21], sedangkan katekin diduga mampu berinteraksi dengan dinding sel dan komponen membrane yang mengakibatkan peningkatan kebocoran bahan sel dari jaringan dan permeabilitas membran (22).

\section{Simpulan dan Saran}

Ekstrak metanol daun kenikir memiliki aktivitas antibakteri tertinggi terhadap $S$. typhi dibandingkan fraksi heksana, etil asetat, dan metanol air pada konsentrasi yang sama. Adanya sifat sinergisme antar metabolit sekunder pada ekstrak metanol menyebabkannya ekstrak memiiki aktivitas antibakteri tertinggi pada $S$. typhi. Oleh karena itu sebaiknya dilakukan skrining fitokimia dengan menggunakan metode kromatografi lapis tipis (KLT) sebagai uji lebih lanjut untuk memastikan adanya golongan senyawa pada ekstrak dan fraksi daun kenikir.

\section{Daftar Pustaka.}

[1]. Sutrisna EM, Kes M. Herbal medicine. Surakarta: Muhammadiyah University Press; 2016.

[2]. Oka IM, Parwata Adi, Kimia J, Kimia L, 
Fmipa O, Udayana U. Obat Tradisional Oleh I Made Oka Adi Parwata Jurusan Kimia Laboratorium Kimia Organik Fmipa Universitas Udayana 2016. 2016;1-71.

[3]. Saifudin A, Usia T, AbLallo S, Morita H, Tanaka K, Tezuka Y. Potent water extracts of Indonesian medicinal plants against PTP1B. Asian Pac J Trop Biomed [Internet]. 1 Januari 2016 [dikutip 8 Februari 2019];6(1):38-43. Tersedia pada:

https://www.sciencedirect.com/science/ar ticle/pii/S2221169115002440

[4]. Hidayat S, Wahyuni S, Andalusia S. Seri Tumbuhan Obat Berpotensi Hias. Jakarta: Elex Media Komputindo; 2006.

[5]. Hidayat S, Napitupulu RM. Kitab Tumbuhan Obat. Jakarta Timur: Agriflo (Penebar Swadaya Group); 2015.

[6]. Mursito B. Tanaman Hias Berkhasiat Obat. jakarta: Niaga Swadaya; 2011.

17]. Shui G, Leong LP, Shih PW. Rapid screening and characterisation of antioxidants of Cosmos caudatus using liquid chromatography coupled with mass spectrometry. J Chromatogr B Anal

Technol Biomed Life Sci. 2005;827(1):127-38.

[8]. Moore S, Safita G, Rismawati E, Sakti E, Syafnir L. Uji Aktivitas Antibakteri Daun Kenikir (Cosmos caudatus Kunth.) dan

Daun Sintrong (Crassocephalum crepidioides (Benth.) S. Moore.) terhadap Bakteri Staphylococcus aureus dan Pseudomonas aeruginosa. 2015;421-8.

[9]. Rasdi NH, Samah OA, Sule A, Ahmed QU. Antimicrobial studies of Cosmos caudatus Kunth . ( Compositae ). 2010;4(April):669-73.

[10]. Lutpiatina L, Amaliah NR, Dwiyanti RD. DAYA HAMBAT EKSTRAK DAUN KENIKIR ( Cosmos caudatus Kunth .) TERHADAP Staphylococcus aureus. 2017;5(2):83-91.

[11]. Febianti Z. Uji In Vitro Efek Antimikroba Ekstrak Daun Kenikir ( Cosmos caudatus H . B . K ) terhadap Methicillin-Resistant Staphylococcus aureus ( MRSA ) Antimicrobial In Vitro Study of Cosmos caudatus H . B . K Leaves Extract Towards Methicillin-Resistant Staphyloc. J Agromedicine Med Sci. 2015;1(2):1-6.

[12]. Dwiyanti W, Ibrahim M, Trimulyono G. Pengaruh Ekstrak Daun Kenikir ( Cosmos caudatus ) terhadap Pertumbuhan Bakteri
Bacillus cereus secara In Vitro The Effect of Kenikir Leaves ( Cosmos caudatus ) Extract on In Vitro Growth of Bacillus cereu s. 2012;

[13]. Sari E ratna; LNSD. Uji Aktivitas Antibakteri dari Ekstrak Etanol dan Beberapa Fraksi Daun Kenikir ( Cosmos caudatus Kunth.) terhadap Bakteri

Penyebab Disentri Shigella sp. 2018;20:14-9.

[14]. Putri DN. Uji Aktivitas Antibakteri Ekstrak Metanol Daun Kenikir ( Cosmos caudatus Kunth .) terhadap Bakteri Salmonella typhi . 2003;

[15]. Ochiai RL, Acosta CJ, Danovaro-Holliday MC, Baiqing D, Bhattacharya SK, Agtini $\mathrm{MD}$, et al. A study of typhoid fever in five Asian countries: Disease burden and implications for controls. Bull World Health Organ. 2008;86(4):260-8.

[16]. Departemen Kesehatan RI. Laporan Nasional Riset Kesehatan Dasar (Riskesdas) 2007. Jakarta; 2008.

[17]. Kemenkes. Pusat Data dan Informasi Profil Kesehatan Indonesia. Jakarta; 2010.

[18]. Njateng GSS, Du Z, Gatsing D, Mouokeu RS, Liu Y, Zang HX, et al. Antibacterial and antioxidant properties of crude extract, fractions and compounds from the stem bark of Polyscias fulva Hiern (Araliaceae). BMC Complement Altern Med. 2017;17(1):1-8.

[19]. Houghton PJ, Raman A. Analysis of crude extracts, fractions and isolated compounds. Lab Handb Fractionation Nat Extr. 2011;113-38.

[20]. Bunawan SN, Bunawan H, Baharum N, Amin NM, Noor NM. Cosmos Caudatus Kunth: A Traditional Medicinal Herb. Glob J Pharmacol. 2014;8(3):420-6.

[21]. Ramadhan F, Mukarramah L, Risma FA, Yulian R, Annisyah NH, Asyiah IN. Flavonoids From Endophytic Bacteria of Cosmos Caudatus Kunth. Leaf As Anticancer and Antimicrobial. Asian J Pharm Clin Res. 2018;11(1):200.

[22]. Helander IM, Nurmiaho-Lassila EL, Ahvenainen R, Rhoades J, Roller S. Chitosan disrupts the barrier properties of the outer membrane of Gram-negative bacteria. Int $\mathrm{J}$ Food Microbiol. 2001;71(2-3):235-44. 